Educational Research for Social Change (ERSC)

Volume 8 No. 1, April 2019

pp. $14-40$

ersc.nmmu.ac.za

ISSN: 2221-4070

\title{
Ensembles of Life: Developing an Affirmative and Intensive Concept in Educational Research
}

Susan Naomi Nordstrom

University of Memphis

snnrdstr@memphis.edu

\begin{abstract}
In this article, I share how I developed an affirmative and intensive concept, the ensemble of life, in a postqualitative study about family history genealogy. Intensive concepts are new concepts that are developed using alternative methods, and seek to affirm what is being lived as well as open up possibilities for different ways of living. Data assembled during a postqualitative study about family history genealogists and the objects (e.g., photographs, documents, and other artefacts) they use to construct their ancestors provided fertile ground for intensive concept development. The excess of the objects bloated preexisting concepts and warranted a new concept, the ensemble of life, to describe the work of objects in family history genealogy that affirms that work and opens it up to becomings. The ensemble of life is a loose grouping of a person's trajectories - or lines-that are formed by the objects in a deceased person's life, the sensations associated with those objects, and the virtual potential of those objects.
\end{abstract}

Keywords: postqualitative research, objects, Deleuze, intensive concepts, family history genealogy, ethics

\section{Copyright: (C) 2019 Susan Naomi Nordstrom}

This is an open access article distributed under the terms of the Creative Commons Attribution NonCommercial License, which permits unrestricted non-commercial use, distribution, and reproduction in any medium, provided the original author and source are credited.

Please reference as: Nordstrom, S.N. (2019). Ensembles of Life: Developing an Affirmative and Intensive Concept in Educational Research. Educational Research for Social Change, 8(1), 14 40. http://dx.doi.org/10.17159/2221-4070/2018/v8i1a2

What happens when we turn our attention to objects in educational research? How do paths of inquiry change? What knowledge do those paths generate? In past scholarship (e.g., Nordstrom 2013, 2015a, 2018) about objects (e.g., photographs, documents, and artefacts) used in family history genealogy, I examined how objects shift methodological paths of qualitative inquiry into postqualitative spaces. In particular, the work of objects in family history genealogy collapsed the binaries of human, nonhuman, living, and deceased, and rendered the terms in constant motion-an assemblage. This assemblage generated different paths of inquiry. In this article, I turn my attention to how those paths generated different knowledge in educational research. 
While family history genealogy is usually viewed as a hobby or career, it can be considered a nontraditional educative space. Family history genealogy is usually a self-directed educative space in which people engage in historical inquiry, usually about their family members or community leaders. These inquiry processes involve navigating a variety of archives and other resources to obtain and interpret historical objects in order to learn more about family members' or community leaders' lives. Adult participants in the study frequently discussed how they learned how to do family history genealogy through books, genealogy groups, genealogy conferences, and personal research. Almost all of the participants also discussed how they taught others about the subject. For them, family history genealogy was an educative space that focused on objects, the connections between objects, and possible interpretations of those objects and connections. These objects materialised a rich assemblage of practices that became fertile ground for intensive concepts. Intensive concepts are creative thought experiments that generate new ways of conceptualising what is being lived.

As I analysed data generated by the assemblage, I began to notice concepts at work in the dissolution of human-nonhuman, living-deceased binaries. These concepts included Deleuze and Guattari's (1994) events, Deleuze's (1993) the fold, Deleuze's (2015) concept of a life, and the Deleuzoguattarian (1987) map. As these concepts and data lived and worked together in the assemblage, they stretched and pulled each other into unanticipated spaces. These movements asked me to explore a variety of disciplines to follow the constantly arranging assemblage I call my study. The ever-shifting arrangements asked me to experiment, to create something else to affirm the work of objects in family history genealogy. These experimentations generated the affirmative and intensive concept, the ensemble of life.

The ensemble of life is a loose grouping of a person's trajectories-or lines-formed by the objects (e.g., photographs, documents, and other artefacts) in their life, the sensations associated with those objects, and the virtual potential of the objects. In this article, I articulate this by sharing five ensembles of life generated during the study. In each ensemble, I focus on one of the following constitutive concepts of the ensemble of life: events (Deleuze \& Guattari, 1994), the fold (Deleuze, 1993), a life (Deleuze, 2006), and the Deleuzoguattarian (1987) map. First, I explore the sensations associated with events in "A Mother Ensemble." Second, I examine the relays between the actual and virtual of events in "A Great-Uncle Ensemble." In the third and fourth ensembles-"A Partner Ensemble" and "A Grandmother Ensemble I" - I explore the animating forces of the fold and a life, respectively. I then map those ensembles to my grandmother's ensemble ("A Grandmother Ensemble II) to explore how the ensemble of life is always in connection to other ensembles of life. I conclude the article by arguing for intensive concept development in educational research with objects.

\section{A Mother Ensemble}

The participant, a retired professor, drove from her home in a larger city in Nebraska (United States) to our two interviews in her childhood home (also in Nebraska), a former funeral parlour in which she kept most of the objects associated with her family. During the initial interview, she told me about a set of Haviland china that her mother took from her parents' foreclosed home in lowa in the late 1920s. When we met for a follow-up interview, she served tea using that china (Image 1). ${ }^{1}$

\footnotetext{
1 Images 1-19 are from data assembled during the study described in this article, which was approved by the researcher's institutional review board. The researcher photographed all images with informed consent from participants. Images 20-27 are from her family collection with informal permission granted by immediate members of the researcher's family. Unknown photographers took these photographs.
} 
Image 1: Haviland China

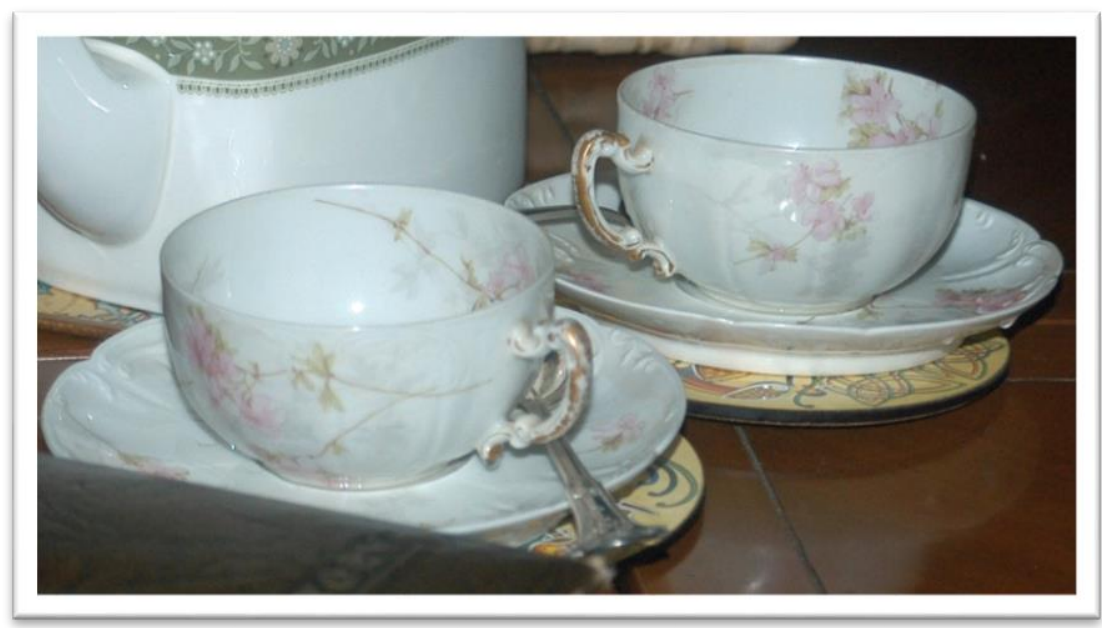

As I drank tea from the china and thought about its story, the affect of the china washed over me and became my entry point into the participant's mother's ensemble of life. In this section, I explain how objects carry sensations and how those sensations serve as entry points into ensembles of life.

When the participant first told me about the china, she said her mother did not want any information in the family records about her Haviland china for fear of embarrassing her family. According to the participant, her mother, who died in 1995, was ashamed that the china told the story of her family's financial issues during the 1920s. The participant, however, disagreed with her mother. She told me that during the 1920s her parents, newly married, lived in Nebraska while her grandfather, grandmother, and uncle lived on a Western lowa farm (Image 2) with several mortgages on it.

\section{Image 2: A Foreclosed Home}

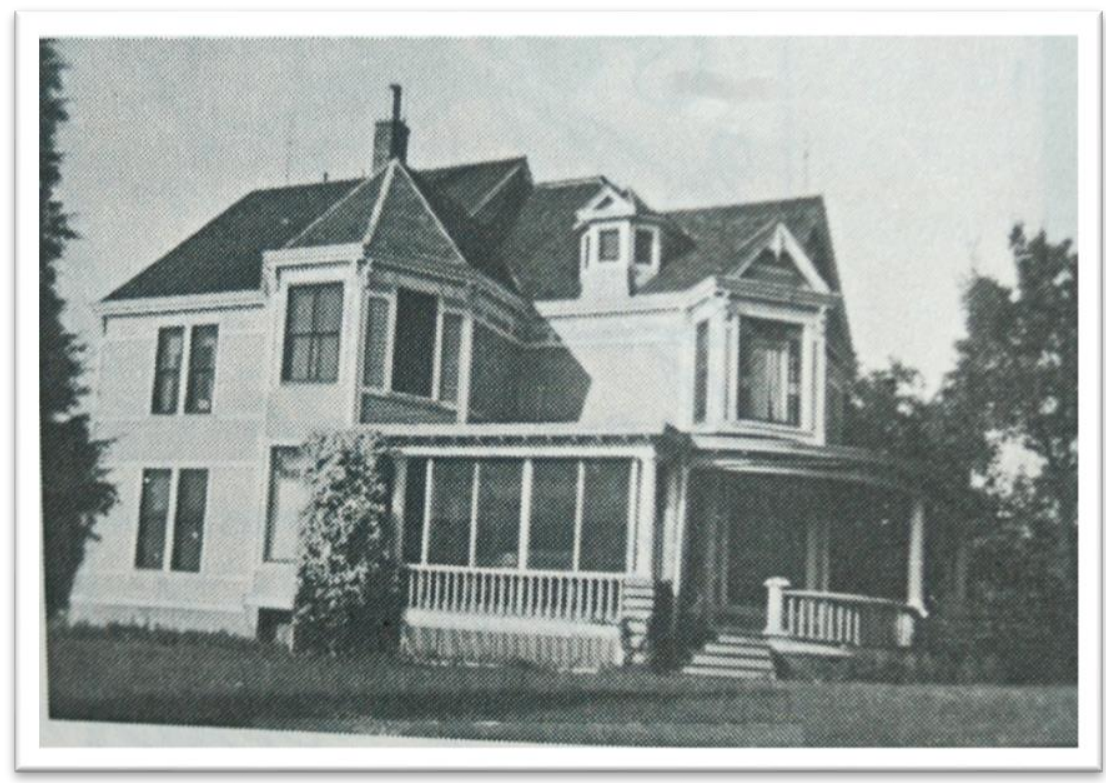

To repay the loans, the participant's grandfather became a migrant worker during the winter in addition to his farming duties. Her grandmother moved to a small town in Nebraska to work as a cook in a restaurant. Her uncle abandoned the family entirely. The participant's mother sent any extra money to her parents. Despite the family's efforts to repay the loans, the bank foreclosed on them and put the farm and the contents of their house on the auction block. Before the foreclosure auction, the grandmother called her daughter and asked her to go to the locked-up house and retrieve some items, 
including the Haviland china. The participant's mother slipped into the house and retrieved those items. After the auction, their farm, home, and the remainder of their personal belongings were gone, sold to the highest bidder.

The Haviland china commemorated the event of a foreclosed farm and home. While Deleuze and Guattari (1994) theorized the monument as a commemoration of an event, the objects of family history genealogy also commemorate events. They wrote:

\section{A monument does not commemorate or celebrate something that happened but confides to the ear of the future the persistent sensations that embody the event: the constantly renewed suffering of men and women, their re-created protestations, their constantly resumed struggle. (p. 176-177)}

While we drank our tea, the participant said about losing a home and all its contents: "I thought how dreadful that must have been . . . really hard." The event of reclaiming the china crossed space and time and entered into my consciousness, which "trace[d] directions, double movements and migrations" (Deleuze, 1994, p. 220) of the china. I kept thinking about the story of the china-it seemed that the china absorbed, or embodied, the event of a foreclosed home and the family's troubles.

For some reason, the sensations associated with the event of the china affected me more than other events in the participant's mother's life and, thus, became my entry point into her ensemble of life. I could also have been affected by the mother's button collection (which represented well over 60 years of collecting and organising) that the participant shared with me (Image 3 ).

\section{Image 3: Buttons}

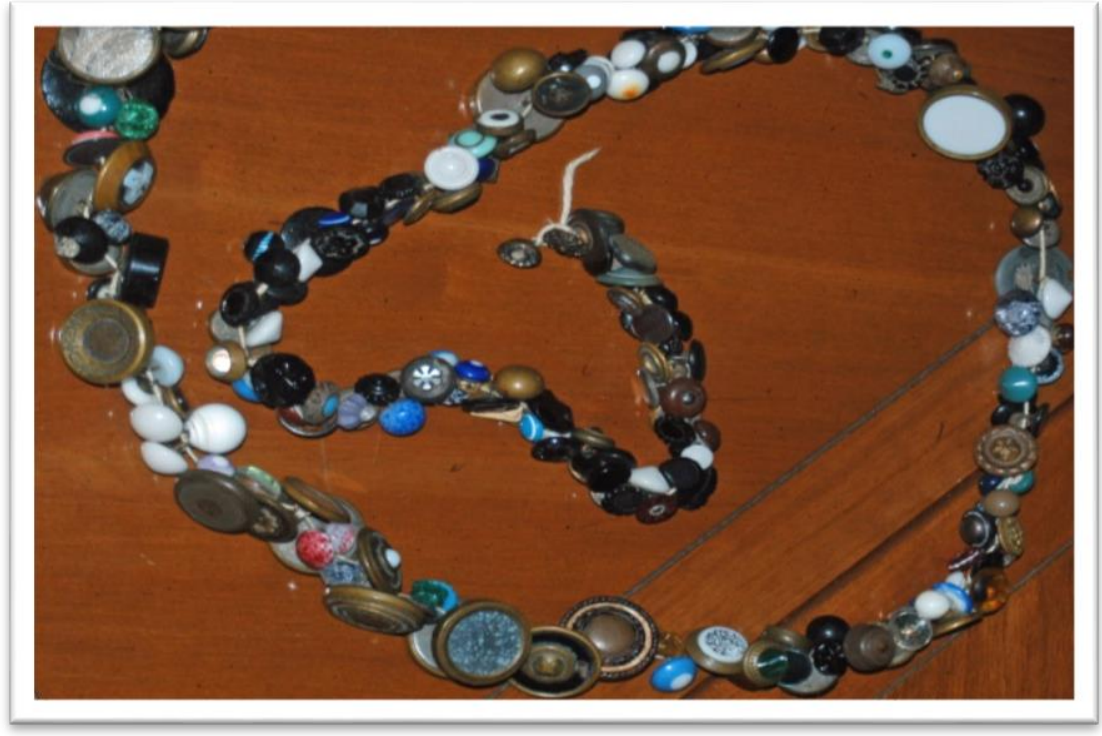

Other objects associated with the mother's life might also have passed through me and affected me differently. Every object creates a different line that contributes to the ensemble of life. Each line creates a different chronology of events that operates in a coexistence of time. For example, the line formed by the china begins in the 1920s, and the button collection creates a line that spans the 60 years of its existence. The ensemble of life, then, is constituted by numerous lines formed by objects that commemorate events and resonate with sensations. 


\section{A Great-Uncle Ensemble}

On a sun-drenched winter day, I drove into a small Nebraskan town with a population of 68 people to interview a woman in her post office/natural food/antiques store on Main Street where I parked my car. As I exited the car, I was taken aback by a face looking out a window at me. On closer inspection, I realised that the face was a painting on a building. I chuckled and asked myself, what was I getting myself into today? I also noticed a park covered by three feet of snow and five-foot drifts next to the participant's store. Elaborate paintings of people and businesses on the buildings (e.g., one building was painted as a dentist's office and another was painted as a general store) emerged from the drifts, and indiscernible objects poked out of the snow. I later learned the participant and her partner had spent about 20 years working on this park, purchasing land and buildings, painting the buildings, gardening, carving innumerable objects, and so on. While the participant shared hundreds of objects with me during the interview, I became spellbound by the connections she made between her park and her great-uncle. In this trajectory, I examine the relays between her great-uncle and the presentday paintings and carvings that populate the park.

As we sat in her store, she told me, "This is my great-uncle," and showed me an advertisement for the book he wrote in 1917, Direct-Method Physical Development (Image 4).

Image 4: An Advertisement



The book was a treatise on abdominal health and contained information about bathing, clothing, eating, and drinking. I had heard of books extolling various healthy habits written during this time, but I had never seen such an advertisement. The participant told me, "I think I inherited my great-uncle's strangeness." My curiosity was piqued.

She told me more about her great-uncle who had immigrated to Nebraska in 1887 from Germany, and served as a German translator for the United States during World War I. After that, he moved to Washington State to work as an assistant cashier for the Pacific Telephone and Telegraph Company. While in Washington, he purchased part of an island in the Columbia River, which he developed as a tourist attraction named, The Forest Glade Zoo. 
Image 5: A Zoo



As the participant showed me the promotional photographs (e.g., Image 5) her great-uncle made for the zoo, I learned that the zoo did not have animals, except for those that already inhabited the island. He used materials from the natural surroundings, such as logs and moss, to make life-sized statues of men, alligators, bears, and other creatures. I became curious to learn about the possible connections between his zoo and the paintings and snow-covered carvings I saw when I parked my car. I asked the participant about those connections, and she replied, "Oh yes, I think I have my great-uncle's blood in me."

The participant told me that she did not know anything about the zoo and the photographs of it when she began to purchase land and build her park that commemorates the town's history. When a cousin gave her the photographs, she formed a connection between her park and her great-uncle's zoo, a connection she understood as her great-uncle's blood running through her body. She frequently said throughout the first interview, "Oh, we could go and see that, but it's covered in snow." Consequently, she gave me a brochure describing the park, and we discussed it. The park, occupying nine of the 15 lots on Main Street, includes: a restored one-room school house, where many of her family members attended school; a garage including restored artefacts from a local 1916 barbershop; a restored office area that was once part of a nearby town's train depot; facades of buildings (e.g., a dental office and an automobile mechanic shop); a "privy path" of five donated outhouses; and the town's historical society-which she founded - that includes genealogical records of all families who lived or are living in the town, typed copies of handwritten diaries of prominent citizens, and other information.

After numerous weather problems during the late winter and spring, I was finally able to see the park that summer during a follow-up interview. While the restorations of the schoolhouse, barbershop, and office are incredible, I most enjoyed the whimsical surprises in the park. Like the participant's greatuncle's zoo, the park is filled with man-made humans and animals, for example, her partner, an acclaimed wood carver, has made numerous carvings of birds, animals, and people (Image 6). 
Image 6: Carvings

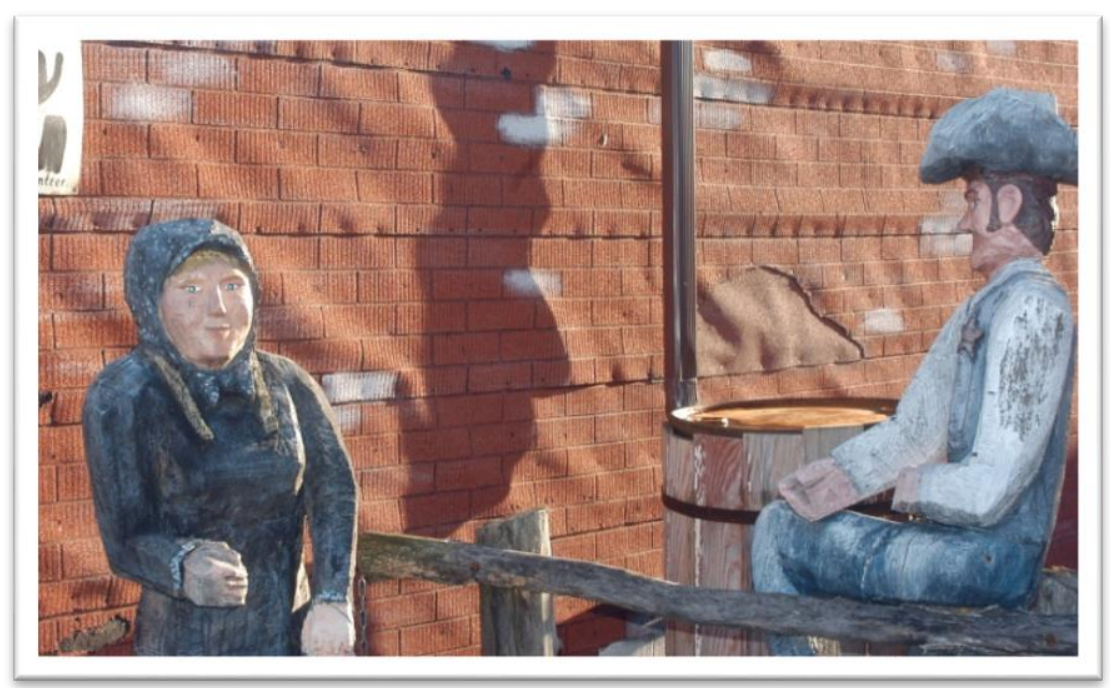

The participant herself had painted prominent community members (e.g., mayors, bankers, and business owners) and her family members on the facades and buildings (Image 7).

Image 7: A Banker

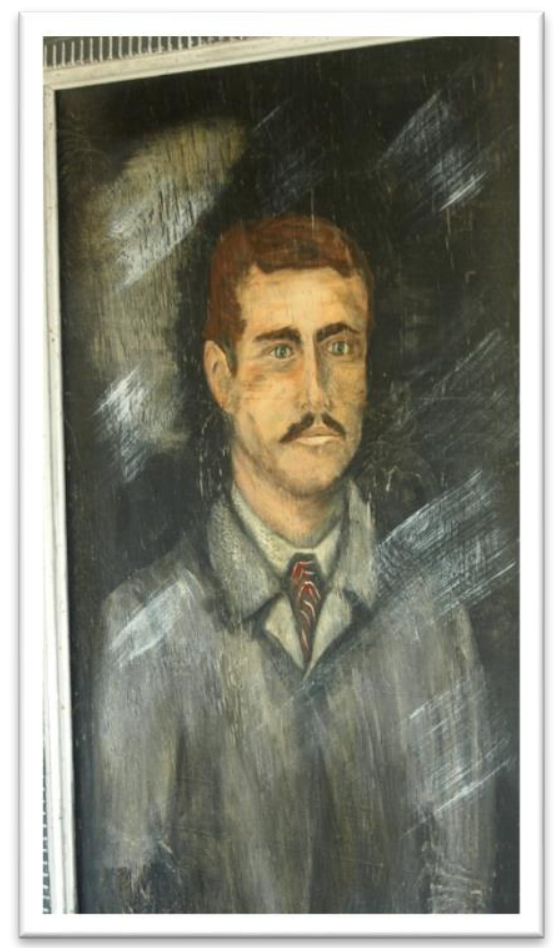

She also planted native plants, including varieties of prairie grasses and wildflowers throughout the garden (Image 8). 
Image 8: A Park

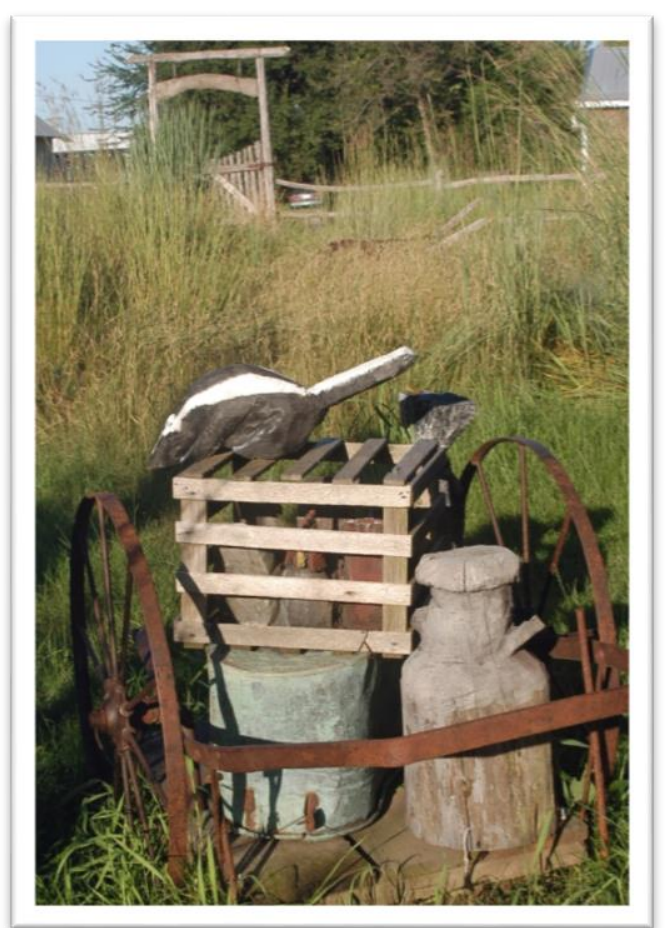

An inexplicable sensation gripped me as the participant and I walked in the park that early evening. My mind returned to one of the promotional photographs she showed me during our initial interview, a photograph of her great-uncle standing with one of his statues in the zoo he created nearly 90 years ago (Image 9).

Image 9: A Great-Uncle Revisits a Park/Zoo

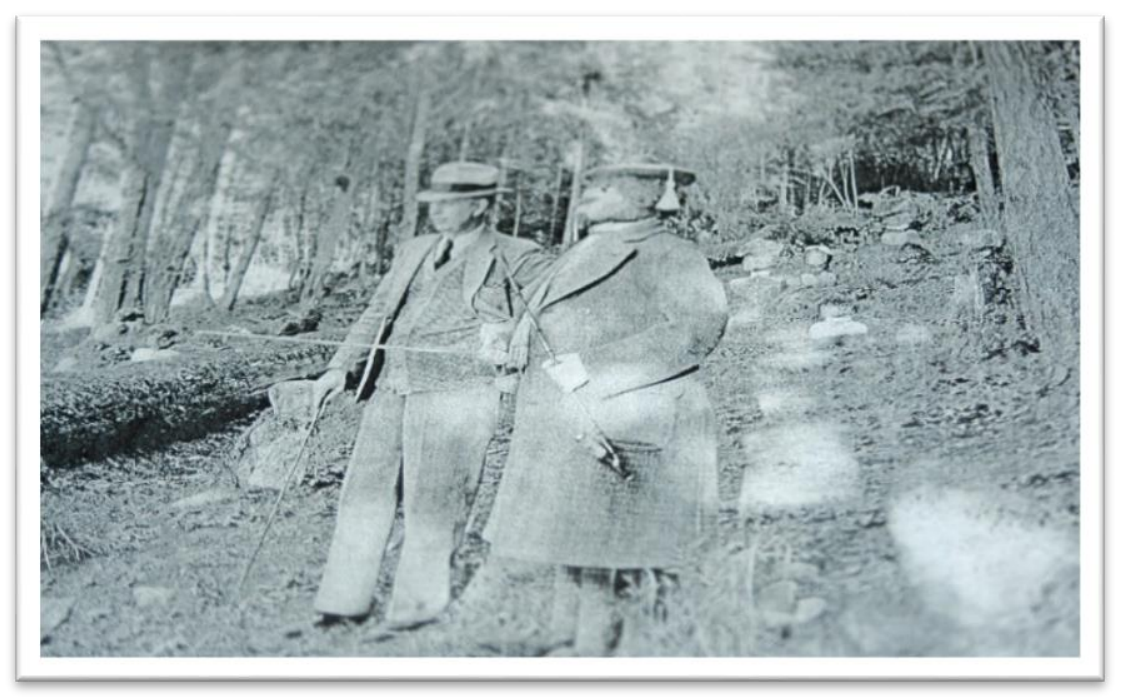

I kept expecting to see him in this park - thinking he might poke his head out of the prairie grass and join our walk. The connections between her great-uncle's zoo and the participant's park were undeniable. I said to her, "I think he is here, I just feel it. I can't explain it." She replied, "I feel like he is revisited through me."

The verb "to revisit" is of interest here. While some may consider the participant's use to be a production of her heart and mind, it can be considered as the indiscernibility between the actual and virtual that Deleuze (1989) discussed as follows: 
The indiscernibility of the real and the imaginary, or of the present and the past, of the actual and the virtual, is definitely not produced in the head or the mind, it is the objective characteristic of certain images which are by nature double. (p. 69)

That is, the objective characteristic of the park is both the great-uncle's zoo and her park. The actual and virtual denote a coexistence of time in which the past, present, and future are entangled together. The park is always entangled with the zoo-the park and zoo render the distinctions between times and places indistinct, and the verb, revisit, marks the lack of clarity between the park and the zoo. Each creation is both part of the park and part of the great-uncle's zoo. Deleuze (1989) also wrote:

The actual image and the virtual image coexist and crystallize; they enter into a circuit which brings us constantly back from one to the other; they form one and the same "scene" where the characters belong to the real and yet play a role. (p. 83-84)

In other words, all the carvings in the park are real, and they call up the moss-covered creations in the great-uncle's zoo. Each carving, painting, and plant in the park is an actualisation of the great-uncle's zoo-the park's creatures are past, present, and futures to come. The park, then, is best understood as a tight circuit between the actual and virtual, such that the great-uncle is always visiting the park.

The objects that constitute the ensemble of life are entangled with the actual and virtual so that the actual and the virtual are indiscernible with/in the objects. Such indiscernibility is not something a person feels or thinks - it is there with/in the objects. It can, however, be sensed, as evidenced by the participant's statements about her great-uncle's blood that runs through her body, his strangeness that she inherited, and his revisits in her life. But I, too, experienced that indiscernibility as I formed connections between the park and the zoo. The objects that constitute the ensemble of life are a tight circuit of relays between the actual and virtual.

\section{A Partner Ensemble}

In the preceding ensemble, I mentioned the participant's partner who helped build the park on Main Street. She frequently mentioned him during our interviews, but did not discuss him at length, and I learned that she would tell me what she wanted to tell me. When I asked for more information about objects and ancestors that I sensed she had a special connection with, she curtly said, "I told you all I'm going to tell you about it." I sensed that the participant felt a special connection with her partner by the way she talked about him. For example, she called him her partner for some time before she shared his name with me, and her voice changed when she talked about him. And so, I did not ask her for more details about her partner. However, she did tell me about him in her own ways-through his work in the park and through her cat, who watched the interviews. In the initial interview, she told me about his carvings in the park (Images 6 and 8 ) and his restoration work with the schoolhouse and her family's log cabin (Image 10). 


\section{Image 10: Some Restorations}
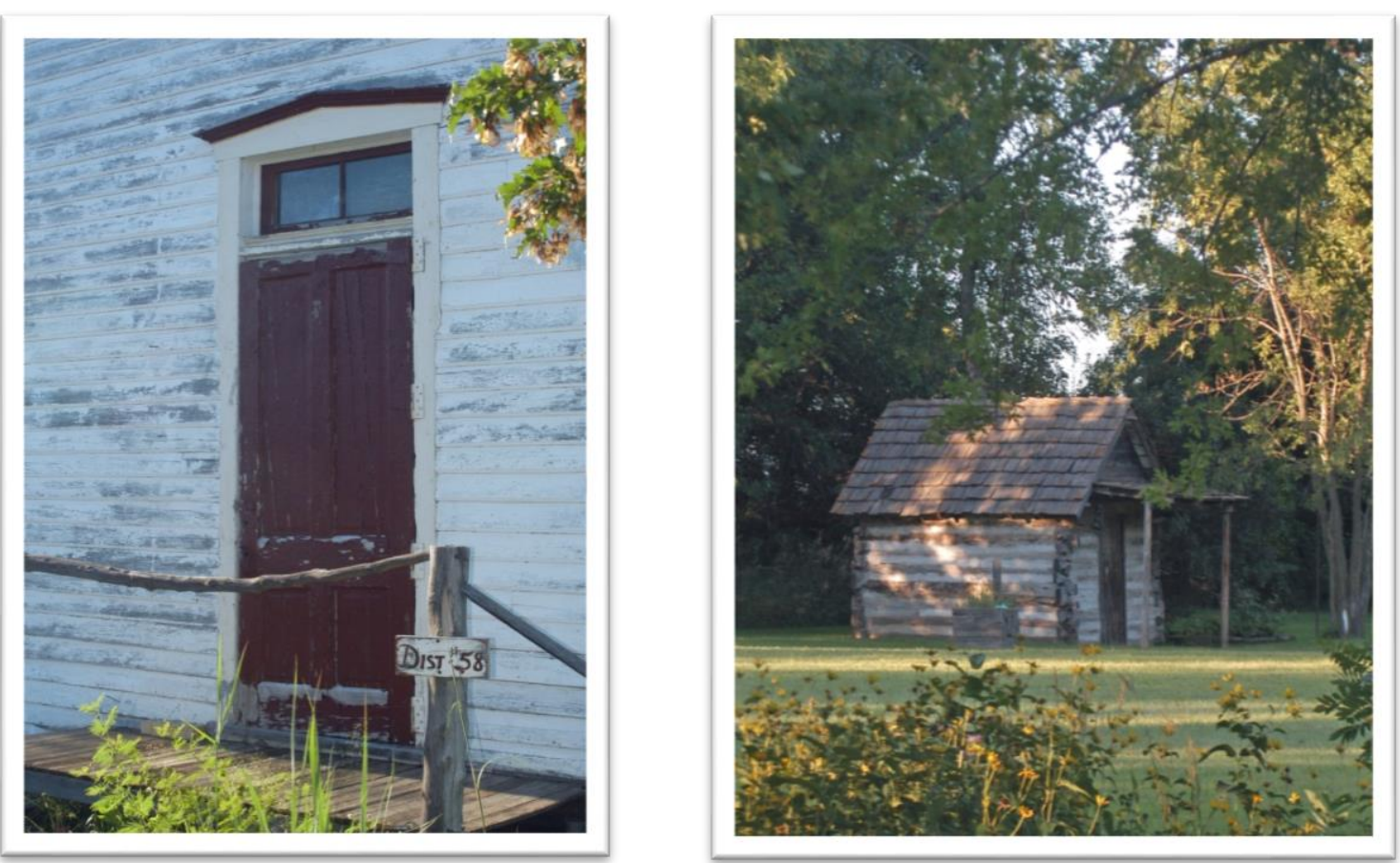

During the follow-up interview that summer, I was able to see his work, the work through which I came to know him. In the initial interview, I also learned about her cat who had an unanticipated connection to his life. In this section, I explain how I came to know the partner through the folds between human, nonhuman, living, and deceased.

After our initial interview, I asked the participant about her cat, a polydactyl Maine Coon, who patiently watched the entire four-hour interview (Image 11).

\section{Image 11: A Cat}

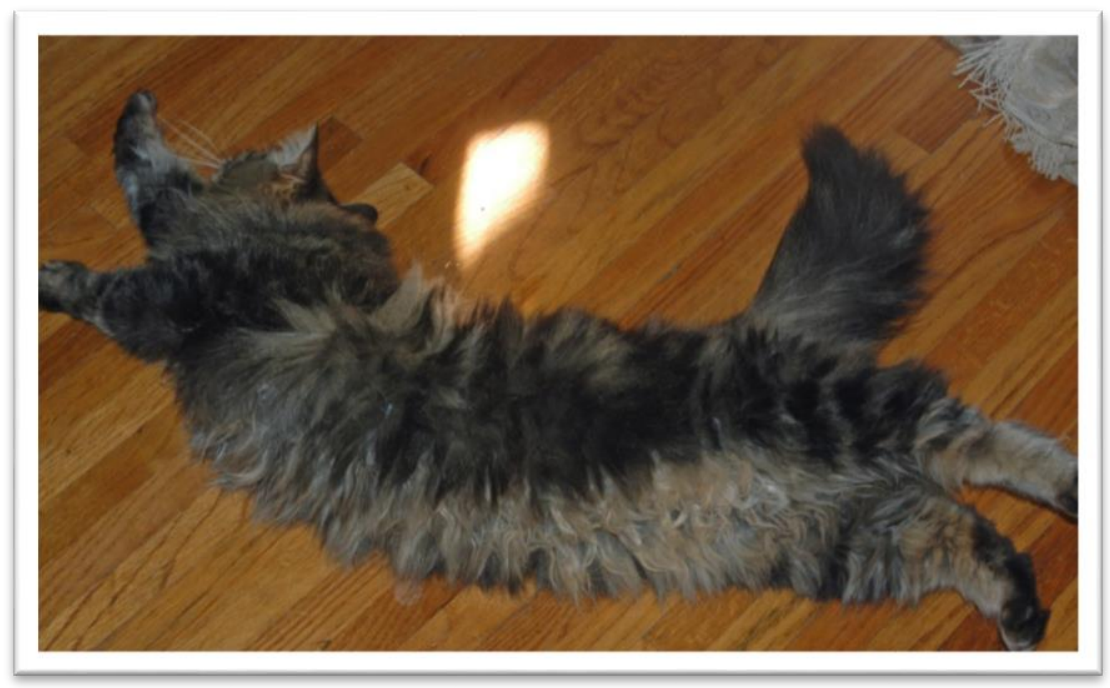

She told me her partner had hated cats, especially this cat. When her partner was dying in hospital, the cat ran away. While visiting him, she told him about the runaway cat. He whispered, "She will return." On the day he died, she went to his carving shed and found the missing cat, staring at her. Before the partner's death, the cat was not very friendly to people. However, after his death, she 
became friendlier. The participant believed that her partner lived on through the cat because the cat took on characteristics (warmth toward others and friendliness) she associated with her late partner.

As I drove home from the initial interview, I kept thinking about the cat and how she disrupted the human-nonhuman binary. Derrida (2008) wrote:

Thinking about what is meant by living, speaking, dying, being, and world as in being-inthe-world or being-within-the-world, or being-with, being-before, being-behind, beingafter, being and following, being followed or being following, there where l am, in one way or another, but unimpeachably, near what they call the animal. It is too late to deny it, it will have been there before me who is (following) after it. After and near what they call the animal and with it-whether we want it or not. (p. 11)

In other words, animals provoke us to think differently about humans and nonhumans, and living and nonliving. I thought about how the cat watched the entire interview and occasionally interrupted it for petting sessions. I thought that the participant's partner had been there, watching the entire interview. As I petted the cat, it drew me into the folds of living, nonliving, human, and nonhuman. Being, in this interview, was folding-being amongst all those folds. I began to understand the cat as a force that overtook me with folding, unfolding, and refolding binary terms.

During our follow-up interview that summer, I learned a bit more about the participant's partner and sensed the rhythmic bass of the fold. As we walked through the park, she told me about late night paintings and carvings when she and her partner were creating the park. She would get up in the middle of the night and paint a surprise for him, just to see if he would notice. He would do the same, only he would carve a small piece of wood. The next morning always presented a challenge-one of them would have to find the new painting or carving in the nine lots on Main Street while the other looked on in anticipation. Everywhere I looked, I saw his carvings peeking out of the prairie grass (see Image 8), and I played with interactive carvings, for example, a carving of a woodpecker that pecked the tree bark when you pulled a hidden string (Image 12).

Image 12: A Woodpecker

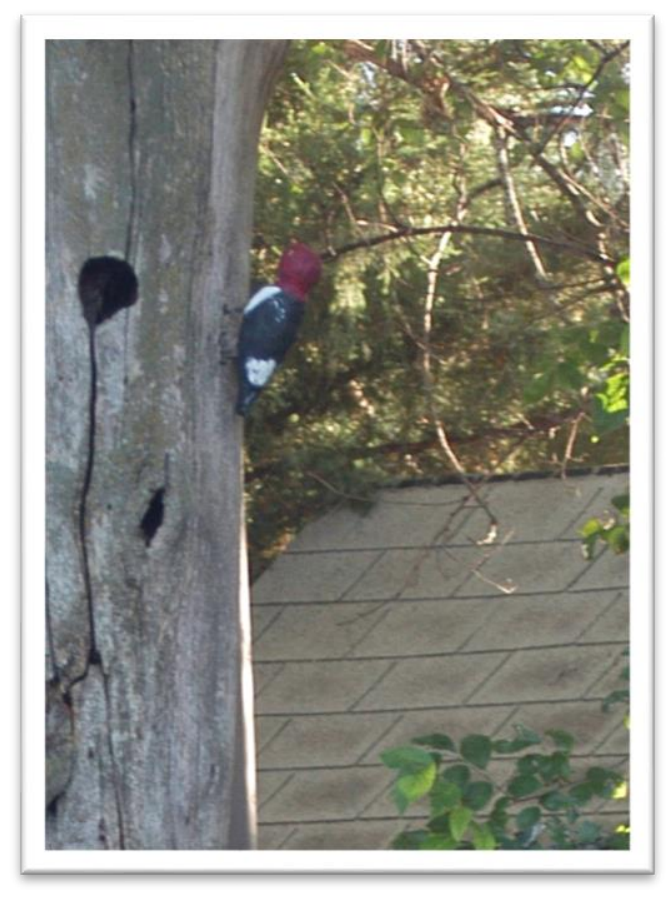


I also saw his restoration work with the school and log cabin (Image 10). The rhythm of the fold was undeniable as the park became a space of folds between humans and nonhumans. In that record-heat of the early summer evening, those folds formed a rhythm for my gait as I came to know more about the partner through his carvings and restorations that populated the garden. As I walked through the park, I folded into his folds.

As I saw the partner's carvings, petted the cat, and listened to the participant tell me what she would about him, a "condition of the possibility of melding, perception, being, sensation, and subjectivity" (Conley, 2005, p. 180) appeared, that is associated with the fold. I came to know the partner by the carvings, which echoed his friendliness and laughter across the park, and by the cat who rubbed her (his) scent on my legs. The carvings and cat melded with the partner so much that I sensed, perceived, those indiscernible folds. Ontology became a rhapsody of folds that swept me away with/in its rhythmic melody. The ensemble of life overflowed with melodic folds of being between humans, nonhumans, living, and deceased. In this way, we are always coming to know a person with/in a rhapsody of folds.

\section{A Grandmother Ensemble I}

For 30 minutes of a nearly four-hour interview, another participant's voice, normally breathless from the words that excitedly poured from her mouth, slowed as she read a transcript of her grandmother's journal, and talked about photographs connected to the journal. As the participant, a volunteer English as a Second Language and Citizenship instructor at area meat-packing plants and libraries, read from the journal, her eyes filled with tears. The walls between the home in which the interview took place and the foggy winter day outside collapsed as a fog-filled intensity filled the room. The woman who wrote this journal, and whom the participant loves dearly, seemed to give the participant pause. In this ensemble, I examine that intensity and pause-a life.

The journal, Glimpses of My Biography, was written in 1941 and contains five sections, each with a provocative ending (Image 13).

\section{Image 13: A Journal}

\section{GLIMPSES OF MY BIOGRAPHY}

Mother and father were married March 4,1886 and I was born on March 2, 1887. Mother's

girthood home was one half mile south of old Liberty Hill church and cemetery where

mother's mother and father and sisters are buried. It was an old fashioned big two-room log

house with a fireplace and a long porch clear across the front, facing east (1 think). Aunt Add

house with a fireplace and a long porch clear across the front, facing ea

In the first section, the grandmother described childhood events in rural Arkansas. For example, she described her family, her childhood home built by her father (Images 14 and 15), her school, childhood games, the church she attended, and her love of daydreaming. 


\section{Image 14: A Family (Grandmother is on the left)}

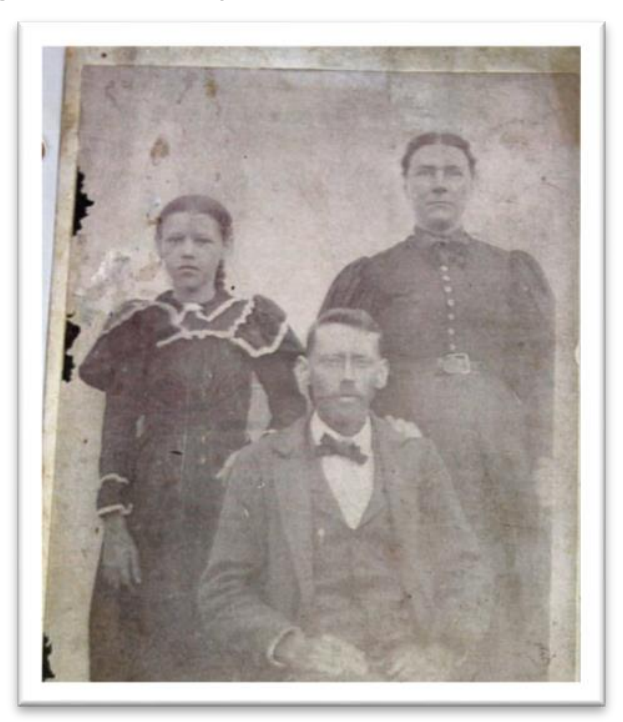

Image 15: A Childhood Home

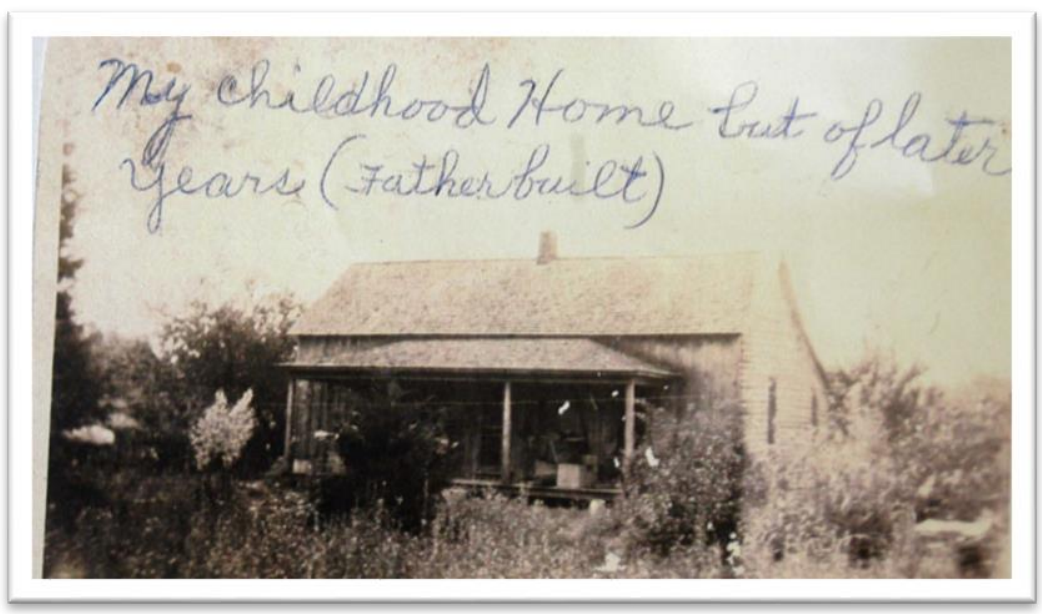

The first section ends: "Left here until March 2, 1941" (she does not provide a beginning date for the journal). The second section described her young adult life. For example, she described her first job, teaching, and her courtship and marriage (Images 16 and 17), and her father's death in 1905.

Image 16: To Teach School (Grandmother is in last row, far left)

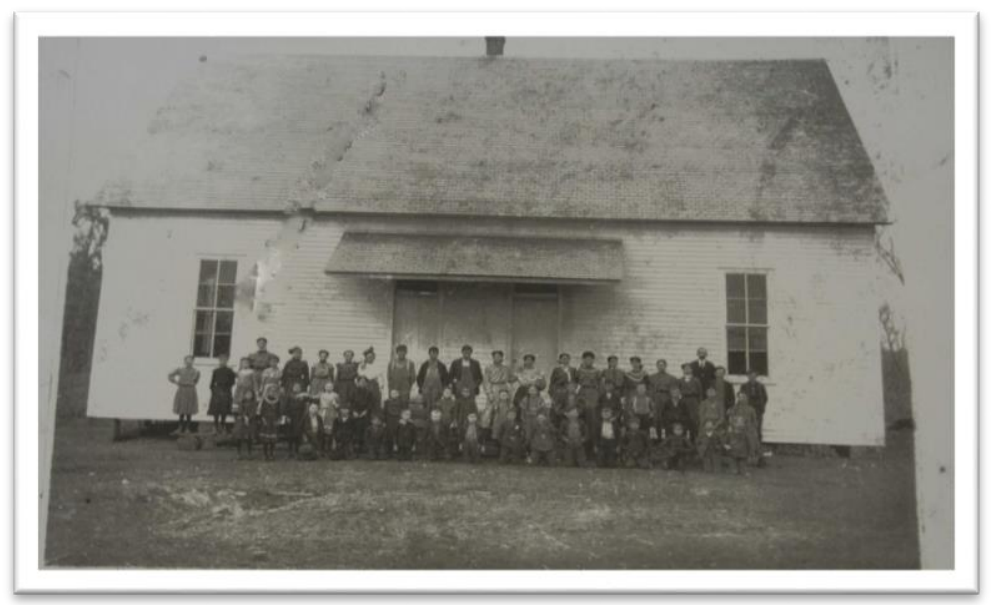




\section{Image 17: A Husband}

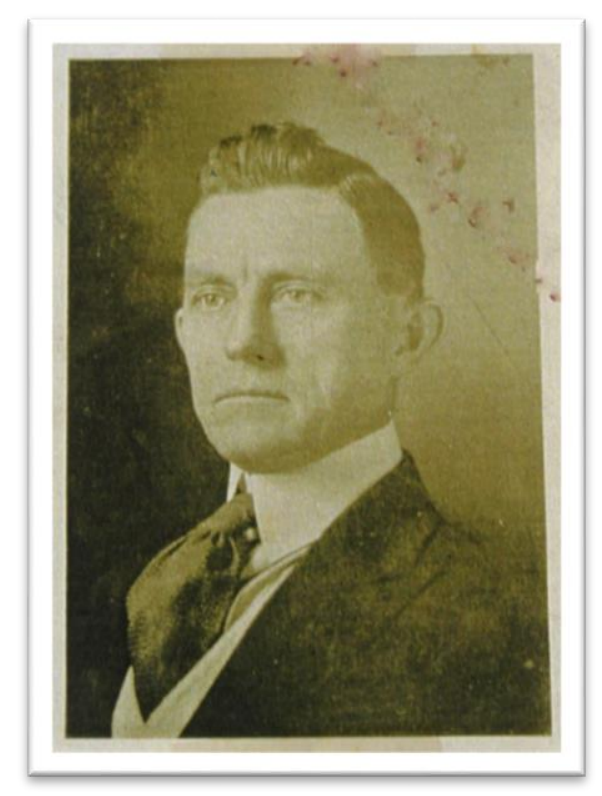

The grandmother wrote the following about her father's death from appendicitis:

I loved my father dearly and I was grief stricken beyond words. I shall never forget his last words to me when near the close. I wanted so to do something for him-he seemed so restless-and I asked what he wanted and he said, "I want Life." These words were forcibly recalled when my husband too said those very same words.

The sentence, "I want Life," captured my attention. It became a sensation that was actualised in the journal as each page resounded with a desire for life. She concluded the second section of her journal with: "If I live and have time, I may write more."

The third section (which described the adult lives of her three children, her friends, her husband's physical and mental decline, which she attributed to poor business dealings, her frequent moves across the country, and her husband's death of an unnamed illness) ended:

Now I'm tired. These have been a few of the highlights in our life and if God lets [me] live I'll write more but since I must face an operation soon, I'll close for now praying I may again write in this book. March 8, 1941.

She did not mention which operation she faced. On April 20, 1941, after a month's absence from writing in the journal, she did share some information about the operation in her journal.

On March 13, 1941, the grandmother underwent a hysterectomy. Benrubi (1988), in his history of the hysterectomy, suggested that the modern hysterectomy was advanced in the 1940s with the use of "fluid therapy, blood banking, intravenous therapy, and most importantly antibiotics" (p. 538). The grandmother does not describe in detail the surgery (full, partial, vaginal, and abdominal), the surgeon, or the medical treatments (antibiotics, blood banking, and anaesthesia) available to her in 1941 in Arkansas. However, given that she ended the third section of the journal with "If God lets [me] live . . ." one can imagine that she worried about the operation and the potential effects it might have on her life. After little more than a month's convalescence, she ended the journal with "It's a glorious spring and so good to be alive." 
The grandmother's desire for life prior to her hysterectomy, as well as her father's and husband's pleas for life before their deaths provide a way of thinking about Deleuze's (2006) conception of a life (Image 18).

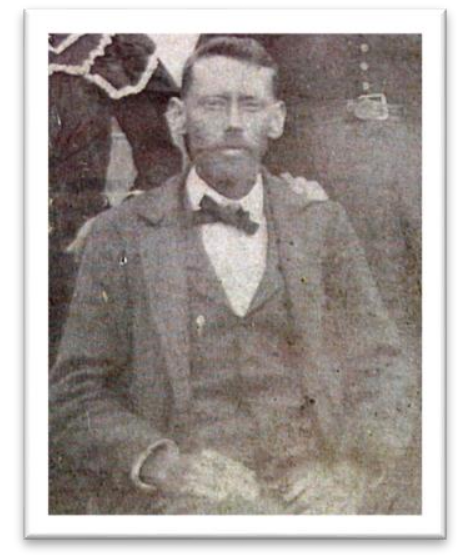

Image 18: I Want Life

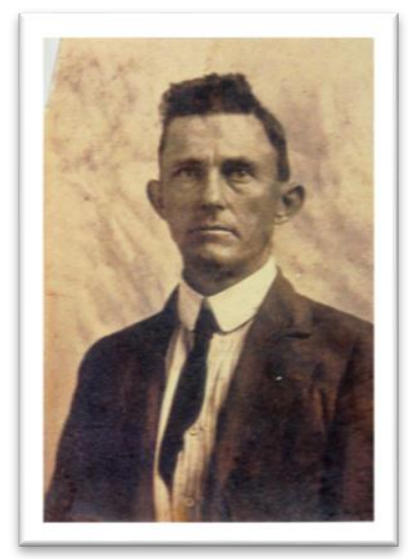

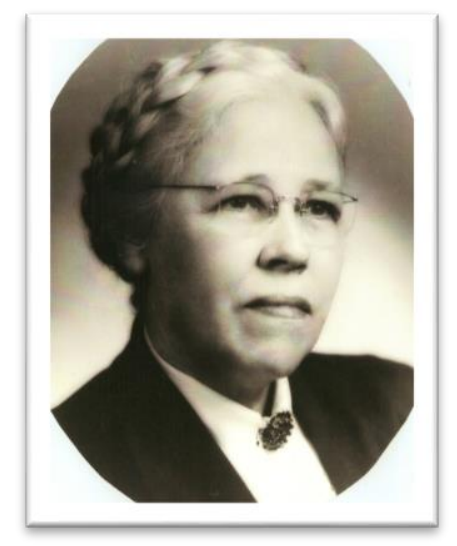

Their medical issues can be thought of as wounds, which Deleuze (2006) described as "incarnated or ... actualised in a state of things and lived experience. A wound itself, however, is a pure virtual on the plane of immanence that leads us to a life" (p. 389). The actual wounds (appendicitis, an unnamed illness, and a hysterectomy) in three people's lives, coupled with their desire for life points to a life, a virtual force of potential.

Each statement was made "at that point of its [life's] fading in a moment between life and death, a life lived in excess of a subject, beyond consciousness" (Grosz, 2007, p. 297). With those statements, the grandmother, her father, and her husband appealed to that excess for more days "share[d] with the weather, the ocean, gravitational forces, even the chemical transformations out of which they are formed and to which they return" (Grosz, 2007, p. 297). They desired more life-the sun shining on their faces, gravity pulling their feet to the ever-turning earth, time spent with their family and friends, and so on. Deleuze's concept of a life, like the virtual, is a force of potential and possibility that animates the statements and the objects associated with their lives. In this way, the grandmother's, her father's, and her husband's desires for life are always being fulfilled.

Grosz (2007) explained, "It is this shared life, aligning life with nonliving forces, that provides the condition under which life creates, makes, invents, that is, adds to the nonliving a new force of virtuality, new singularities" (p. 297). In family history genealogy, that life can emerge from objects. The nonliving people associated with the objects continue to live because of the "irreducible persistence of life" (Deleuze, 1989, p. 74) that pumps the nonliving with virtuality. In this way, the journal and the photographs provide the life that the grandmother, her father, and her husband so desired. That desire, that life, gives the living-the participant-pause as the immensity of a life presents itself to the living and nonliving.

When I listen to the digital audio recording of the 30 intensity-filled minutes during which the participant read from the journal, the intensity of a life is palpable. The air became heavy, as if the fog outside entered into the home and surrounded us. A life surrounded us as it emerged from the journal and photographs. As the participant read from the journal, it seemed that we-the participant, her grandmother, her great-grandfather, her grandfather, and me-sat at the participant's kitchen table folding together in the foggy intensity. 
A life is a persistent and productive force in the ensemble of life. The force of a life is what makes the living and nonliving endlessly fold together, and is also part of the rhapsodic ontology I discussed in " $A$ Partner Ensemble" because it sweeps the living away into the folds of living and nonliving. In this way, a nonliving person continues to live on in folds in the ensemble of life such that a desire for life is always being fulfilled.

\section{A Grandmother Ensemble II}

A person's life, even after her death, continues to make unanticipated linkages and ruptures. In this section, I explore how lines in my grandmother Naomie's ensemble of life connect to the lines already described in this article-in order to demonstrate how the ensemble of life is always open to connections with other ensembles. To make those connections, I examine a set of dishes, photographic slides of my grandmother, pets, and the last known photograph of her before she died in 1966.

\section{China Connections}

While I was assembling data, my aunt and uncle called my parents' house to tell us that a distant cousin had downsized her home and sent our family some dishes she purchased at the auction following my grandmother's death. My aunt and uncle had yet to open the box because they wanted my parents to be there for the occasion. All five of us sat in their living room, eagerly anticipated the opening of the box. My aunt pushed the packing paper aside to reveal the dishes - a set of red glasses and a tea set (Image 19).

\section{Image 19: A Glass and a Teacup}

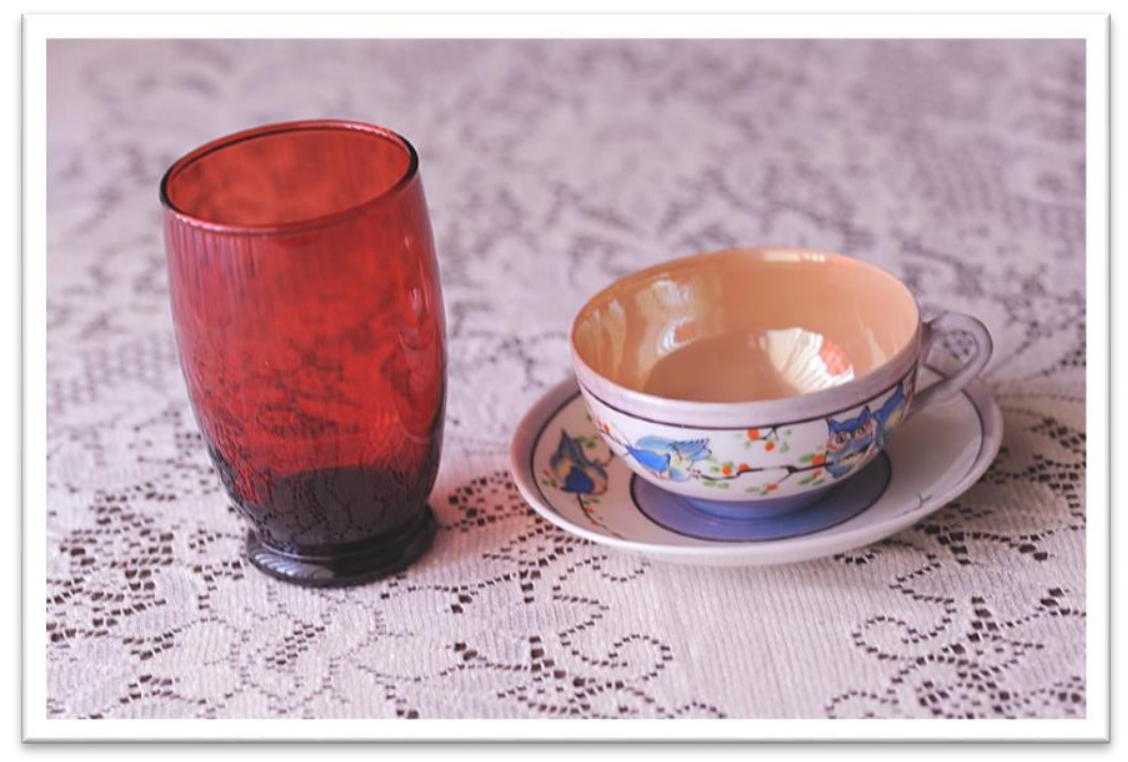

My uncle remembered drinking Kool-Aid from the red glasses, but my father did not remember anything at all about the glasses or tea set. We agreed that my aunt and uncle would keep the red glasses and my parents would have the tea set.

After the decision, my aunt and uncle discussed other objects they had-for example, a set of chipped goblets from my grandmother's house. My aunt said, "They're not worth much. None of this is worth much." I desperately wanted to ask, "How do you value a life?" Instead, I remained silent.

In "A Mother Ensemble," I discussed the Haviland china a participant's mother had reclaimed from a foreclosed home. The participant never mentioned the monetary value of the china other than 
referring to the name of the china, Haviland. Instead, she discussed the dread of losing a home, a sensation she associated with that china. Another participant, who owned an antique shop, gestured around her store and said, "All of this is worth some money, but it isn't valuable, because none of these objects have stories." The objects affect the living with sensations. Deleuze and Guattari (1994) wrote about artwork:

The young man will smile on the canvas for as long as the canvas lasts. Blood throbs under the skin of this woman's face, the wind shakes a branch, a group of men prepare to leave. In a novel or a film, the young man will stop smiling, but he will start to smile again when we turn to this page or that moment. (p. 163)

These comments on artwork can be extended to the objects of family history genealogy. Returning to my grandmother's dishes, those dishes throb with sensation. Every time they are studied, used for dinner or a tea, my grandmother folds into the living. The sensations associated with the dishes and any other objects of family history genealogy have little relation to their monetary value. The sensations - the smiles in photographs, the trees bustling in the wind of a photograph, the hands holding a teacup, and the weight of a hand signing a document-make those objects priceless.

\section{Revisiting Slides}

After I arrived in Nebraska for data assembling, my cousin mentioned my grandfather Nordstrom's slide shows at a family gathering at my aunt and uncle's house. We all groaned and remembered when Grandpa, Naomie's husband, would set up the projector, find a box or two of slides, and call us to the living room. I remembered those times as tedious interruptions of my childhood playtime as my grandfather showed slides of farms, cattle, and golf courses. Still, there we sat, looking at the slides as my grandfather told us about each one. When my grandfather died in 1992, the boxes of slides were split between my father and uncle. I told my father I would like to see them again.

My father set up the slide projector in the basement and told me to come downstairs. As he went through the boxes, some of which I had never seen before featured my grandmother, he told me about each slide as it slipped in and out of the projector and his memory. When he showed me the slide of my grandmother sitting in a field of wildflowers in Colorado during a family vacation he said, "Now do you see where you get your reddish hair?" (Image 20).

\section{Image 20: My Grandmother I}

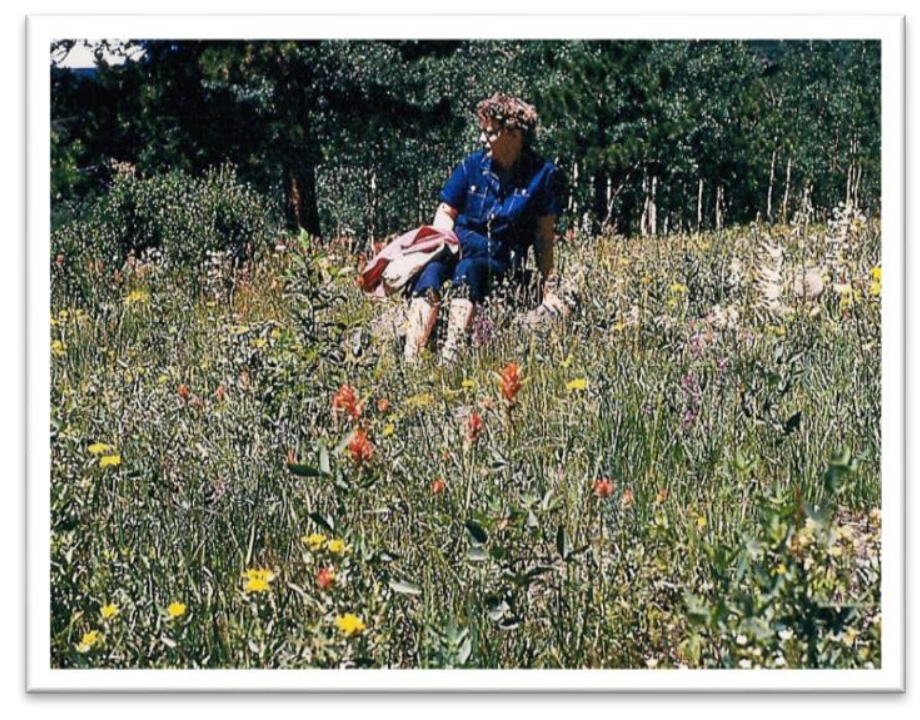


I had never seen a colour picture of my grandmother, whom so many relatives said I look like. I saw my hair (her hair) on the screen. With each passing slide of her, I saw myself-certain gestures, facial expressions, and poses. For example, her concentration while using her new sewing machine seemed to match the way I hunch over when I concentrate on an activity (Image 21).

\section{Image 21: My Grandmother II}

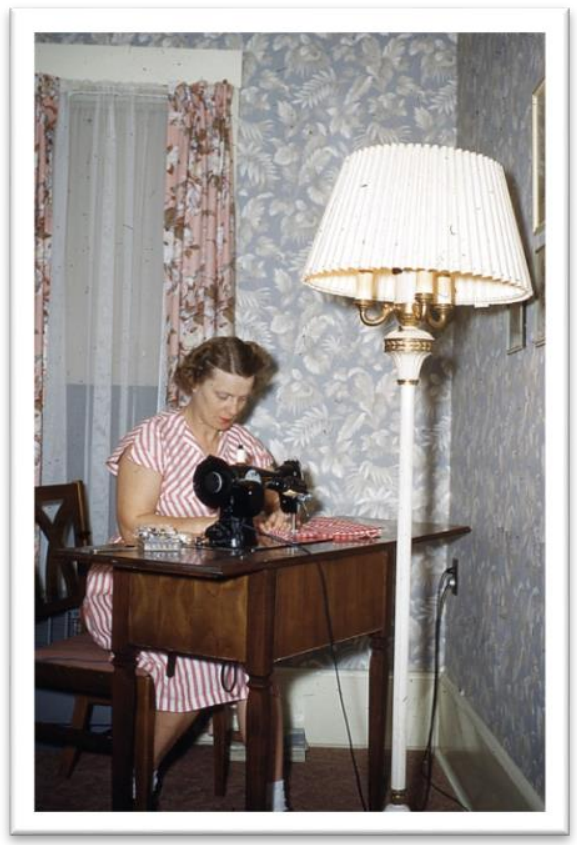

The way her face dropped down when she spoke to my grandfather is the same way I hold my face when I write (Image 22).

\section{Image 22: My Grandmother and Grandfather}

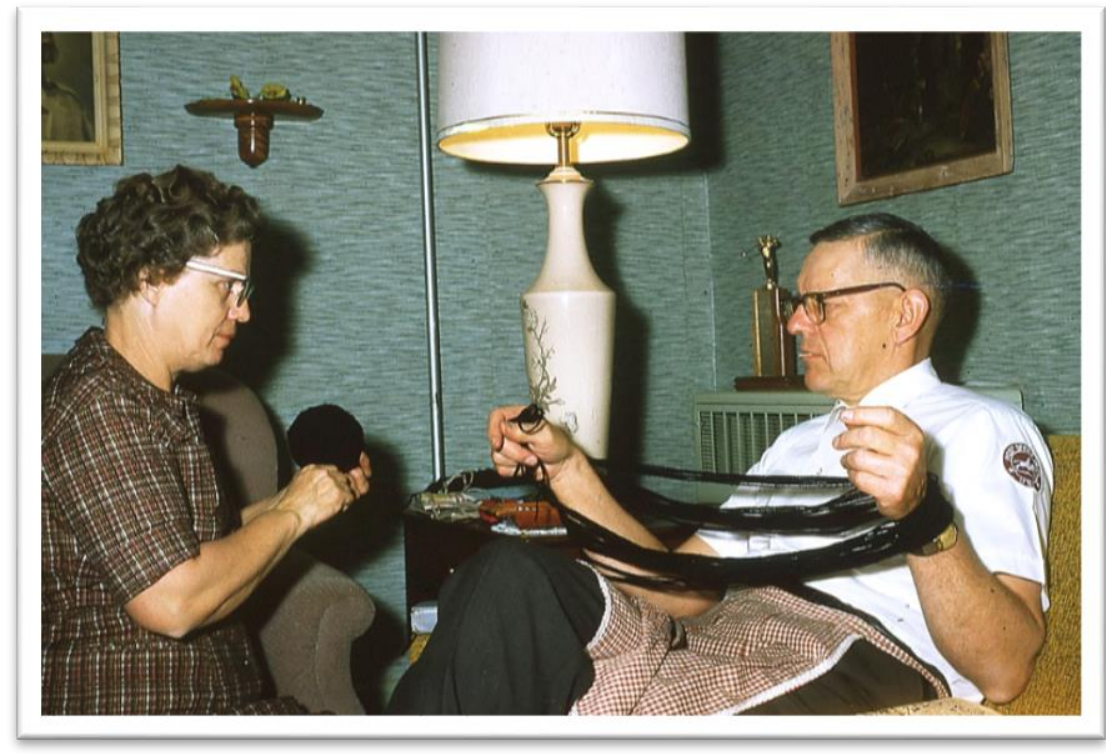

Her excited smile and body that seemed ready to leap for celebration at a family Christmas gathering was something I know my face and body to do when I am excited (Image 23). 
Image 23: My Grandmother III

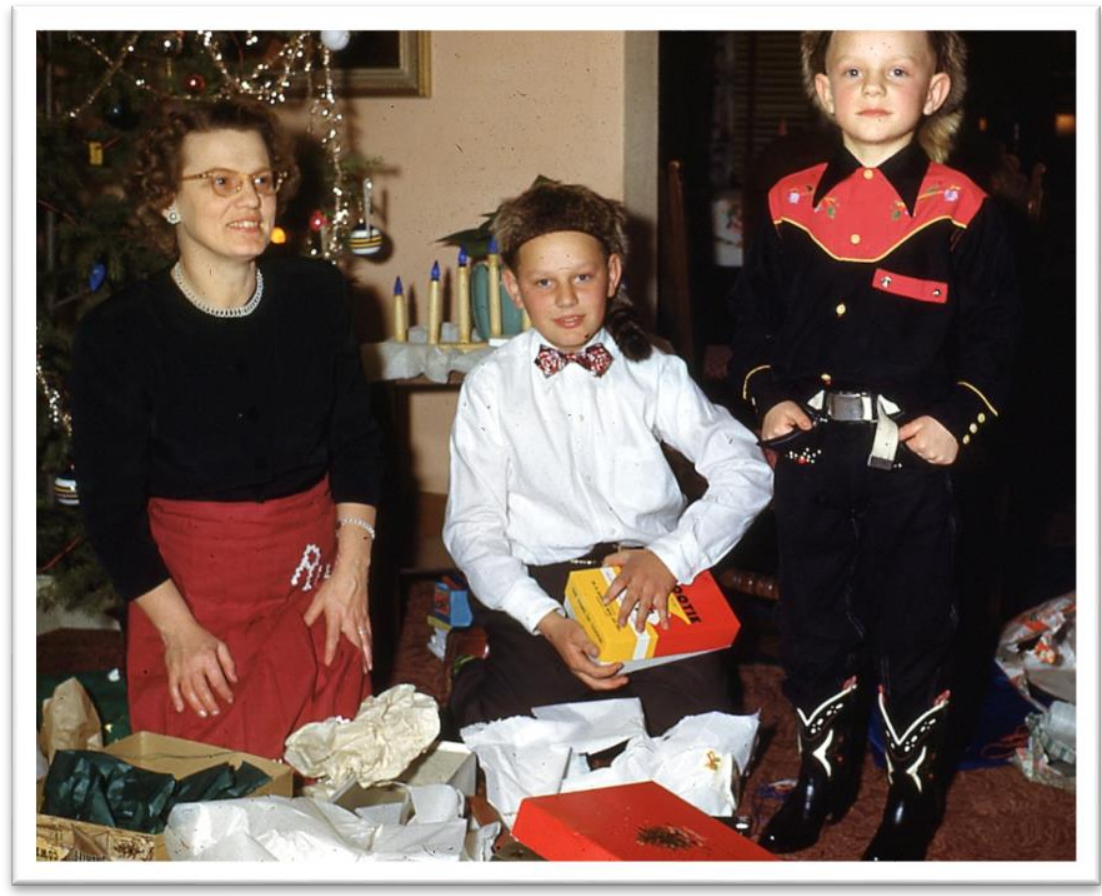

Every slide of her was a reminder of me.

In "A Great-Uncle Ensemble," I discussed the participant's use of the verb, revisit, and how it helped me think of the virtual that always revisits us. Throughout my life, my grandmother's virtual revisited me through my physical appearance. In fact, when I was born, my grandfather Nordstrom said I was a Swanson, her maiden name. However, I did not realise how much I looked like her until I saw my hair (her hair), my face (her face), my body (her body) on the slides, and intimated that my grandmother survives through me. Deleuze (1989) wrote:

The virtual survival of the dead can be actualized, but is this not at the price of our existence, which becomes virtual in turn? Is it the dead who belong to us, or we who belong to the dead? (p. 74)

When I saw those slides, I did not know whether my grandmother belonged to me, or I to her. Who did my (her) face, body, and hair belong to? I became curious about my life-whose life is (was) it anyway? I began to think about my life differently, as a virtual survival of my grandmother, a life that exists in a coexistence of time. Deleuze wrote, "Subjectivity is never ours, it is time, that is, the soul or the spirit, the virtual" (1989, pp. 82-83). My life and her life are perpetually oscillating together in a coexistence of time. In this way, our lives are defined by that oscillation between living and nonliving, as our lives are lived together.

\section{Animal Connections}

During the slide show I described above, my father also showed me slides of his family pets, notably Rags (Image 24) and Mesie, my grandmother's cat (Image 25). 
Image 24: Rags

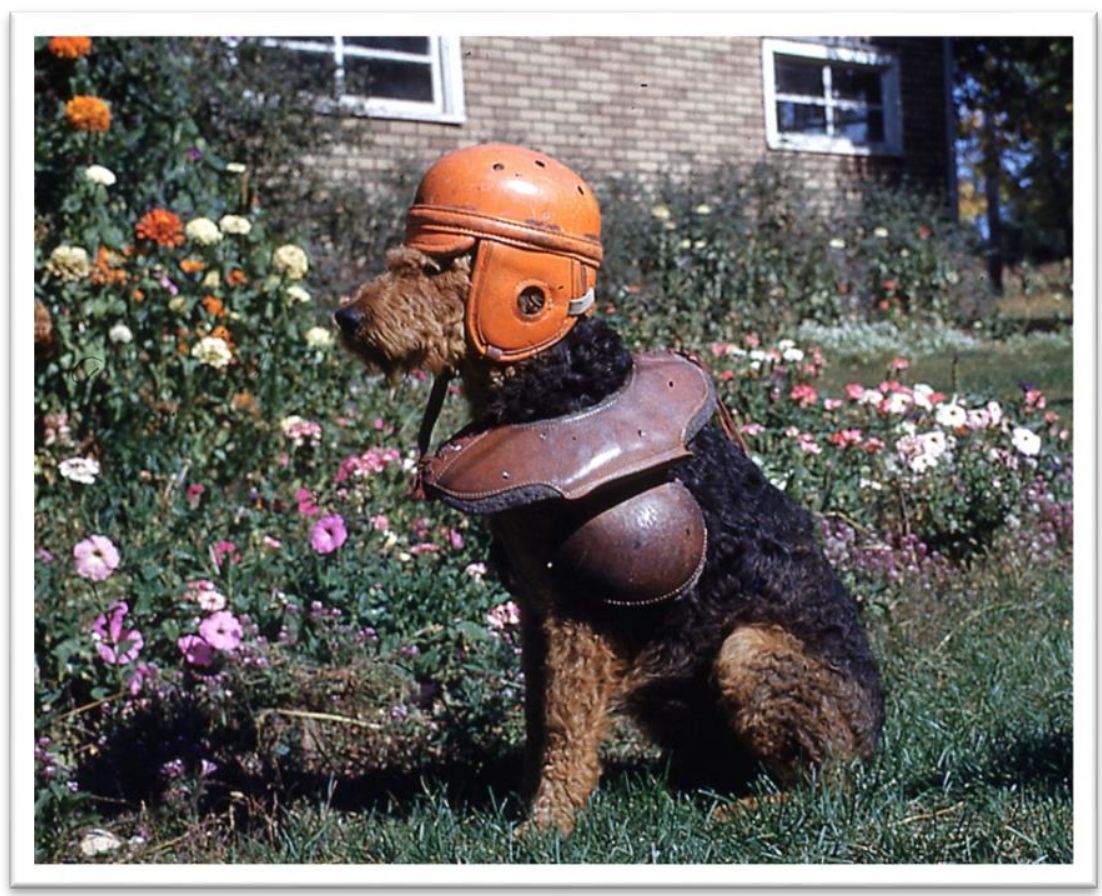

Image 25: Mesie

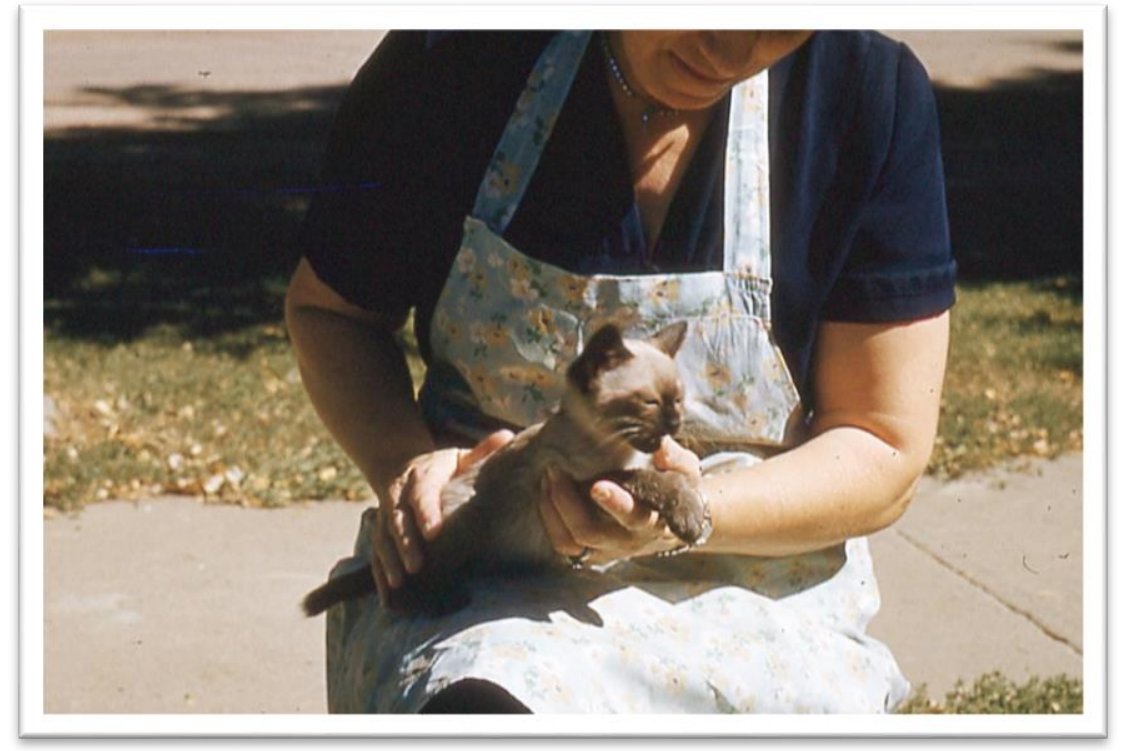

In "A Partner Ensemble," I discussed how the participant felt that her partner lived on through her cat. Her story helped me understand how my grandmother continues to live, or fold, with/in Rags and Mesie.

When my father showed me the slide of Rags, I laughed out loud. I asked, "How did the dog stay so still with a football helmet on his head?" He replied, "I don't know." As we continued to look at the photograph, he said, "Oh, how Mom loved flowers." Before this conversation, he had referred to my grandmother with pronouns, by her first name, or as my grandmother-he never called her "Mom." Derrida (2008) wrote, "It happens that there exist, between the word I and the word animal, all sorts of significant connections" (p. 49). Perhaps Rags, the animal, made it possible for my father to think, to say, "Mom" to me. 
After my grandmother died in March 1966, my grandfather could not give away her cat, Mesie. When he remarried in November 1966, Mesie came to live with his new wife in their new home. According to family members, Mesie never acclimated to the new home. She was sullen and standoffish. It was as if Mesie had to remind everyone of her nonliving owner. Derrida (2008) deconstructed the binary of human-animal and suggested that binary terms work in a multiplicity. He wrote:

Beyond the edge of the so-called human, beyond it but by no means on a single opposing side, rather than "The Animal" or "Animal Life" there is already a heterogeneous multiplicity of the living, or more precisely (since to say "the living" is already to say too much or not enough), a multiplicity of organization or lack of organization among realms that are more and more difficult to dissociate by means of the figures of the organic and inorganic, of life and/or death. (p. 31)

Mesie occupied the heterogeneous space of both living and nonliving. She became a four-legged, tailswishing, and hissing reminder of my grandmother. For example, in a photograph of my grandfather with his new in-laws taken in the late 1960s, he held Mesie as if the cat-my grandmother-were a part of this new family (Image 26).

\section{Image 26: Mesie II (My grandfather, back row, holding Mesie.)}

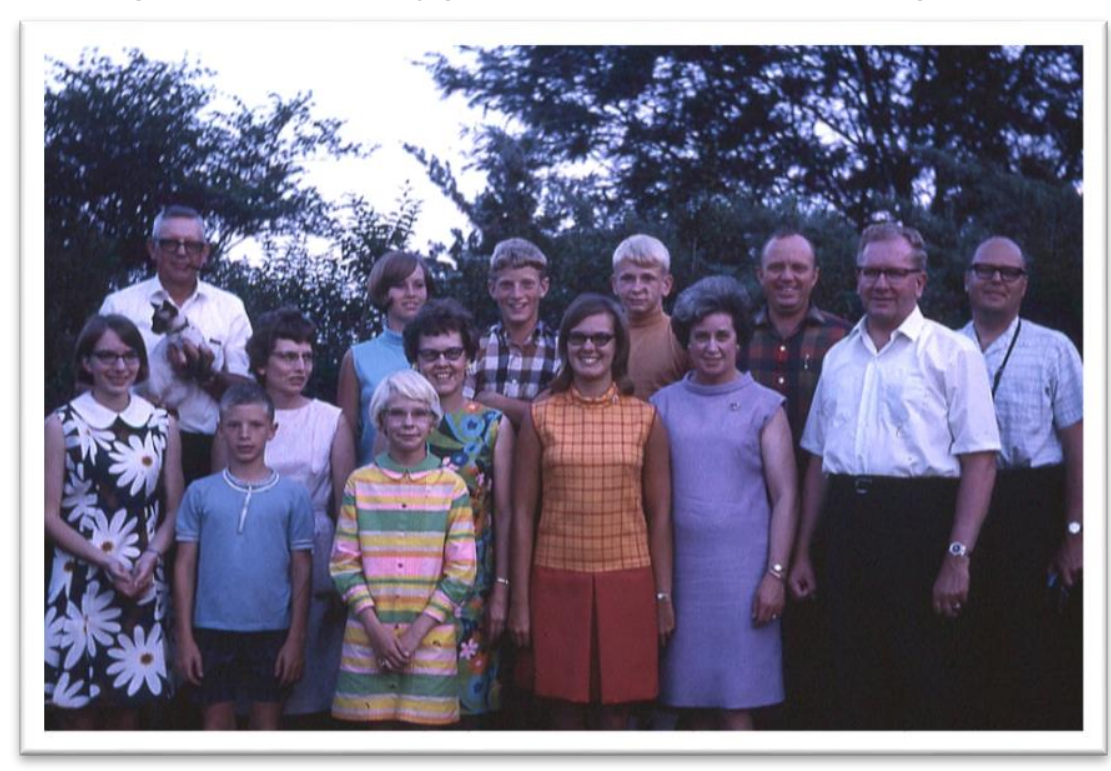

As with the participant's cat, Mesie occupied a space in which it was difficult to know whether my grandmother was dead or in a series of folds between living and nonliving.

Animals, then, provide us with a way to negotiate living-nonliving, human-nonhuman, and other binary terms. Derrida (2008) suggested that perhaps the most tenacious binary division in which we live is that between human and animal, or nonhuman. While seemingly mute, animals respond from the space of swarming binary terms and they force us humans to reckon with that heterogeneous space. Derrida described such being as "being-huddled-together" $(2008$, p. 10). To huddle can also be thought of as to fold. Being is a series of folds that endlessly fold together. Animals can help negotiate that space of folding, or huddling, as they pose in front of flowers, hiss, and rub their scent against the legs of the living. As a cat kneads on your stomach, she reminds you that you, too, are a fold, huddled amongst many folds. 


\section{A Last Photograph}

The last known photograph of my grandmother was taken approximately six weeks before her death of brain cancer while she was visiting family members in Arizona (Image 27).

\section{Image 27: A Last Photograph (My grandmother is on the right.)}

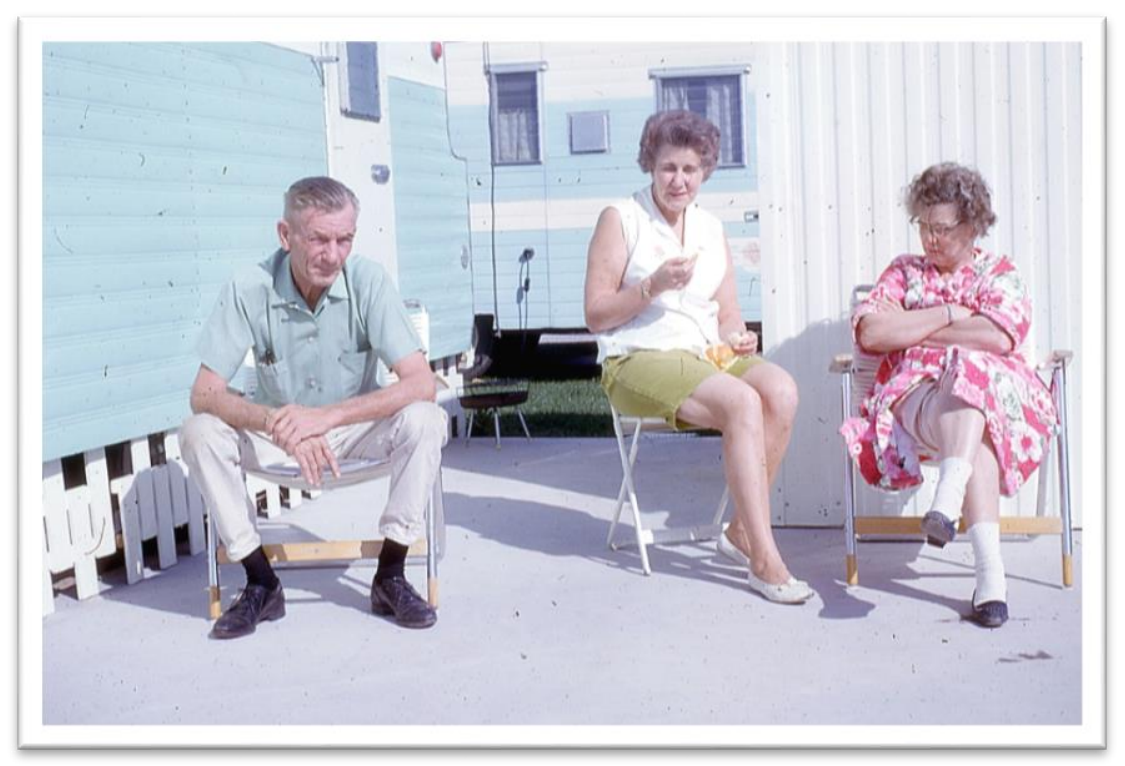

In "A Grandmother Ensemble I," I described how the participant's words slowed with the intensity of her grandmother's journal. In a similar way, the photograph of my grandmother gives me pause as the space between living and dying opens to a life.

I first saw the photograph in the late winter when my parents were out for the evening. While I was assembling data, my father scanned some of my grandfather's slides, and I occasionally looked at his computer folder to study the images. When I saw the photograph on the computer screen, I cried an open-mouthed, soundless, tear-filled, and runny-nosed cry. I do not know why. I have known for a very long time that my grandmother died in 1966 . I suppose I did not expect to see her dress partially lifted by the wind, her ruffled hair, or her face showing the signs of cancer. I had never seen a photograph of her like that before. As I wept, I could not stop looking at the photograph, as if that might somehow save me from tears. Every time I see it, I respond in the same way and, as for the participant who read her grandmother's journal, this photograph's intensity is like no other.

The participant's grandmother's journal was written approximately a month before her hysterectomy, and the photograph of my grandmother was taken about six weeks before her death. In both instances, a life is evident because one woman desires life and the other faces her death. Deleuze (2006) wrote:

Between his life and his death, there is a moment where a life is merely playing with death. The life of the individual has given way to an impersonal and yet singular life, which foregrounds a pure event that has been liberated from the accidents of internal and external life, that is, from the subjectivity and the objectivity of what comes to pass: a "homo tantum" with whom everyone sympathises and who attains a kind of beatitude; or an [ha]ecceity, which is no longer an individuation, but a singularisation, a life of pure immanence, neutral beyond good and evil, since only the subject that incarnated it in the midst of things made it good or bad. The life of such individuality is eclipsed by the singular 
immanent life of a man who no longer has a name, though he can be mistaken for no other. A singular essence, a life. (pp. 386-387)

The journal and photograph give way to a life, because those objects are experienced when death is perceived to be close. Those objects are "bits of experience that can't be fit into a nice narrative unity" (Rajchman, 2000, p. 85). That is, the sensations of intensity-the feeling of being in a time warp, a change in voice, eyes filled with tears - do not fit into a cohesive whole. Those sensations of intensity are haecceity, which Rajchman explained as follows:

An hour of a day, a river, a climate, a strange moment during a concert can be like thisnot one of a kind, but the individuation of something that belongs to no kind, but which, though perfectly individuated, yet retains an indefiniteness, as though pointing to something "ineffable." (2000, p. 85)

In other words, sensations are individuated, they happened in an individual's life, and they are indefinite and indescribable. Haecceity is my tears upon viewing the photograph, the participant's voice caught by the words of the journal. Language strains under those intensity-filled experiences. The virtual, a life, is expressed by those moments of speechlessness and struggles of language. The journal and the photograph and the atmosphere of intensity the participant and I experienced provided a glimpse of a life when both women-her grandmother and mine-perceived that death was imminently close. The journal and the photograph take the breath away, but also breathe a life.

The ensemble of life-similar to the Deleuzoguattarian (1987) map-is always open and connectable to other ensembles of life. Deleuze (1995) wrote about maps: "What's interesting, even in a person, are the lines that make them up, or they make up, or take, or create" (p. 33). In this section, I demonstrated how my grandmother's ensemble of life connects to or takes lines from other ensembles. The other ensembles modified my grandmother's ensemble of life by adding new dimensions to it. Likewise, my grandmother's ensemble added dimensions to the other ensembles. A person's life is always open to new and unanticipated connections, and those connections constantly modify a person's ensemble of life.

\section{Affirmative and Intensive Ensembles of Life}

A focus on the objects of family history genealogy created relational pathways of inquiry that generated the ensemble of life. The relations between nonhuman objects, other nonhumans, humans (living and deceased), and so on warranted a different methodology, methods, and ways of conceptualising data, which I detailed elsewhere (Nordstrom 2013, 2015a, 2018). I also had to develop a way to think about what was happening in the study. Such work demanded that I not fall into a representationalist trap that "limits the goals and impacts of inquiry in the name of social change" (Kuntz, 2015, p. 77). Instead, I had to focus on an "integrated, dynamic, intrarelation among matter and practices" (Kuntz, 2015, p. 77) to generate new possibilities. In the concluding section of this article, I explain how I did this, and the implications of such work in educational research for social change.

Assemblage work is never just a matter of putting the word "assemblage" on a doing and calling it a day. Assemblage work is rigorous for it is never a matter of plugging in concepts to the assemblage or naively thinking one concept explains the work of the assemblage. Events, the fold, and a life provided a consistency with which to think about what that data did and continues to do in the study. These concepts, however, were not apart from the data assemblage (Nordstrom, 2015a, 2018). These concepts were always already there living in the assemblage. I suspect there are other concepts living in the assemblage I have yet to encounter. There was and still is no plugging in to be done, rather, an 
intense relay-between these concepts and how they were being lived-formed during analysis. How the concepts were being lived in the dense and knotty relationships between humans and nonhumans in family genealogists stretched the concepts into different spaces.

These philosophical concepts also linked to other disciplines such as medical fields (e.g., Benrubi, 1988), animal studies (e.g., Derrida, 2008), and local, US, and world history. It was never just one discipline, one concept, or one history. These disciplines, philosophical concepts, histories, and the data assemblage are in constant relay with each other. Guattari's (1984) work with transversals is useful here; he defined transversality as "a dimension that tries to overcome both the impasse of pure verticality and that of mere horizontality: it tends to be achieved when there is maximum communication among different levels and, above all, in different meanings" (p. 18). In other words, transversality asks us to put a maximum of concepts and disciplines in communication with each other to create new paths of inquiry and ways of knowing and being in the world. In so doing, transversality generates affirmative and dynamic responses to the world's constant becomings.

Assemblage and transversal work generates an ethical approach that opens up ways of knowing and being in the world. The requirements set forth by my institutional review board (IRB) about informed consent, which included taking photographs of objects, were met and adhered to throughout the study. However, as most qualitative researchers know, the IRB's ethical requirements are just the beginning of ethical work in qualitative projects (Ellis, 2007; Kuntz, 2015). Moreover, the theoretical framework of a particular study sets forth the ethics that guide a study. In this study, Deleuze's (1993) fold created the ontological rhythms of the study (for a more detailed explanation of this work please see Nordstrom, 2018) and the assemblage provided an ever-arranging framework to work with these rhythms.

In my proposal for the study, I situated the anticipated ethical work of the study by drawing on a sentence from Anne Michaels' (1996) novel, Fugitive Pieces: "Love makes you see a place differently, just as you hold differently an object that belongs to someone you love" (p. 82). I rightfully anticipated that I would come to intimately fold with, love, and care for the folds among the participants, their ancestors, and the objects associated with the ancestors' lives. While Ellis (2007) described a relational and intimate ethics grounded in a humanist version of care, Deleuze's (1993) fold operates in a posthuman framework that creates a relational ethics conceptualised in constant movement. Such an ethical framework asks researchers the following question. "How does a researcher keep folds folding in a procedural ontology?"

This question has no normative answers (Colebroook, 2017). Instead, it invites a myriad of possible responses. Colebrook wrote, "Problems are forces of composition, ongoing events of dynamic learning-again, human and nonhuman" (2017, p. 653). This problem became central to the development of the ensemble of life. How do I harness the forces of humans and nonhumans in this iteration of family history genealogy presented in this study? How do I honour folding folds? How do I create a concept that keeps folds folding? How do I keep the assemblage alive?

Colebrook (2017) challenged the use of extensive concepts in favour of intensive concepts in educational research. Extensive concepts draw on conventional methods that generate data that can be labelled with preexisiting concepts. I could have easily studied family history genealogy in a more traditional manner and, in turn, used existing concepts such as identity or subjectivity to describe the data. Intensive concepts draw on what is happening, what is being lived. In so doing, intensive concepts help articulate the happening, the living, and, in turn, create new concepts (Colebrook, 2017). The ensemble of life functions as an intensive concept. It provides a contingent stability with the assemblage. This temporary stability is a combination of concepts being lived and stretched in the 
assemblage as well as the variety of disciplines needed to understand the movements of those concepts. The ensemble of life is temporary because the assemblage is always in movement, always folding. Something else could happen that could very well alter the concept's course. Intensive concepts affirm the assemblage from which they materialise.

To further affirm the assemblage, I engaged in response data (St. Pierre, 1997), which I developed in Nordstrom (2015b). There, I argued that the response data in my study are both political and ethical data that open up new articulations of knowing and being. In the middle of data assembling, I presented an informal paper about my initial interpretations, the beginnings of the ensemble of life, to a group of participants and sent the presentation to other participants who were not in attendance. I attended to that data and further data generated from conversations with participants about the concept-in-development. Following my graduation, I provided each participant's local library with a copy of my dissertation in which the ensemble of life was developed and featured. Seven months after I graduated, I presented the ensemble of life at an informal meeting of a genealogy group of which several participants were members and, a few months later, at the statewide genealogy conference. Following each meeting, I took fieldnotes about audience responses and studied these data to better understand the work of the concept in the lives of family history genealogists. I considered the data as events that could be reconfigured again and again (Colebrook, 2017), arranging and rearranging the response data to better understand the ethical work of that data. Thus, I was able to keep the folds of data moving in ways respectful to the participants, their ancestors, and the objects associated with their ancestors.

In many ways, the concept, the ensemble of life, was something I gave back to the participants because they gave it to me (Deleuze \& Parnet, 2002). The forces generated amongst humans and nonhumans in the object-interviews generated the concept. Through careful theoretical and transversal work, I worked and reworked those forces as they materialised into the ensemble of life. The response data that ran through and after the study became critical to the concept's development. The forces kept composing themselves, affirming new becomings. This is ethical work-keeping forces affirmatively moving to new becomings, attending to response data, worrying words and theories, and giving back what participants knew to give during object-interviews. This is the ethical work of keeping folds folding in concept development.

Generating affirmative knowledge about what is happening, what is being lived by participants, is ethical work toward social change. Braidotti (2011) wrote that "the ethical ideal is to increase one's ability to enter into modes of relation with multiple others" (p. 286). In other words, affirmative ethics seeks to open up becomings, new ways of being. Intensive concept development does this work. Colebrook (2017) argued that educational research should be active in the generation of new concepts rather than take existing concepts and apply them to educative spaces. Kuntz (2015) argued for practices that engage in a "determination to simultaneously be other than we are and other than we have been" (p. 91). The ensemble of life seeks to do such experimental and creative work. The openended and affirmative ensemble of life shifts understandings about family history genealogy and those who practice it into a space of becoming. This article serves an evocative example of such affirmative and experimental work, and articulates a line of flight for researchers interested in such work to generate affirmative, ethical, and intensive concepts.

In Braidotti's (2012) thoughts about concept creation, she advised, "experimenting with thinking is what we all need to learn" (p. 29). A focus on nonhuman objects and other nonhumans invites us to do experimental thinking that generates new methodologies and concepts to open up different ways of knowing and being. When we turn our focus toward the other side of the binary, which is not privileged in most educational research and the typically extensive concepts that guide it, we can 
better unravel the power relations that uphold binary divisions and categorical imperatives. Nonhuman objects are excessive, "always becoming more than what is - or could be known" (Kuntz, 2015 , p. 83). Such excess invites creative experimentation. We can begin to see the rich assemblages at work in educative spaces, and the complex ways in which humans and nonhumans move with the world. This is transversal work that requires us, many times, to step outside our disciplinary confines and pathways of inquiry (Guattari, 1984). With concept development, we can begin to work in transversals rather than eschew them for extensive and hierarchical ways of knowing and being that uphold existing power relations. We can begin to creatively solve problems by generatively affirming what is happening and, hopefully, making better lives possible. Concept creation allows us to approach the present in order to understand what "we are ceasing to be" (Braidotti, 2018, p. 6) and cultivate "what we are in the process of becoming" (p. 6). Go. Experiment. Become. Create. Generate becomings for others. Transform.

\section{References}

Benrubi, G. I. (1988). History of hysterectomy. Journal of the Florida Medical Association, 75(8), 533538.

Braidotti, R. (2011). Nomadic theory: The portable Rosi Braidotti. New York, USA: Columbia University Press.

Braidotti, R. (2012). An interview with Rosi Braidotti. In R. Dolphijn \& I. van der Tuin (Eds.), New materialism: Interviews \& cartographies (pp. 19-37). Ann Arbor, USA: Open Humanities Press.

Braidotti, R. (2018). A theoretical framework for the critical humanities. Theory, Culture \& Society. Retrieved from https://journals.sagepub.com/doi/full/10.1177/0263276418771486

Colebrook, C. (2017). What is this thing called education? Qualitative Inquiry 23(9), 649-655.

Conley, T. (2005). Folds and folding. In C. J. Stivale (Ed.), Gilles Deleuze: Key concepts (pp. 170-181). Montreal, Canada: McGill-Queen's University Press.

Deleuze, G. (1989). Cinema 2: The time-image (H. Tomlinson \& R. Galeta, Trans). Minneapolis, USA: University of Minnesota Press.

Deleuze, G. (1993). The fold: Leibniz and the baroque (T. Conley, Trans.). Minneapolis, USA: University of Minnesota Press.

Deleuze, G. (1994). Difference and repetition (P. Patton, Trans.). New York, USA: Columbia University Press.

Deleuze, G. (1995). Negotiations: 1972-1990 (M. Joughin, Trans.). New York, USA: Columbia University Press.

Deleuze, G. (2006). Two regimes of madness (D. Lapoujade, Ed., A. Hodges \& M. Taormina, Trans.). New York, USA: Semiotext(e).

Deleuze, G., \& Guattari, F. (1987). A thousand plateaus: Capitalism and schizophrenia. (B. Massumi, Trans.). Minneapolis, USA: University of Minnesota Press.

Deleuze, G., \& Guattari, F. (1994). What is philosophy? (H. Tomlinson \& G. Burchell, Trans.). New York, USA: Columbia University Press.

Deleuze, G., \& Parnet, C. (2002). Dialogues II (H. Tomlinson \& B. Habberjam, Trans.). New York, USA: Columbia University Press.

Derrida, J. (2008). The animal that therefore I am (D. Wills, Trans.). New York, USA: Fordham University Press. 
Ellis, C. (2007). Telling secrets, revealing lives: Relational ethics in research with intimate others. Qualitative Inquiry 13(1), 3-29.

Grosz, E. (2007). Deleuze, Bergson, and the concept of life. Revue Internationale de Philosophie, 61(3), 287-300.

Guattari, F. (1984). Molecular revolution: Psychiatry and politics (R. Sheed, Trans.). New York, USA: Penguin.

Kuntz, A. (2015). The responsible methodologist: Inquiry, truth-telling, and social justice. Walnut Creek, USA: Left Coast Press.

Michaels, A. (1996). Fugitive pieces. New York, USA: Vintage.

Nordstrom, S. (2013). Object-interviews: Folding, unfolding, and refolding perceptions of objects. International Journal of Qualitative Methods 12, 237-257.

Nordstrom, S. (2015a). A data assemblage. International Review of Qualitative Research 8(2), 166-193. https://doi.org/10.1525/irqr.2015.8.2.166

Nordstrom, S. (2015b.) Unfinished, fragmented, shifting, and folding slips toward the political possibilities of response data. In A. B. Reinersten \& A. M. Otterstad (Eds.), Metodefest og øyeblikksrealisme [Methodfestival and realism of the moment] (pp. 200-213). Bergen, Norway: Fagbokforlaget.

Nordstrom, S. (2018). Antimethodology: Postqualitative generative conventions. Qualitative Inquiry 28(4), 215-226.

Rajchman, J. (2000). The Deleuze connections. Cambridge, USA: MIT Press.

St. Pierre, E. A. (1997). Methodology in the fold and the irruption of transgressive data. International Journal of Qualitative Studies in Education 10(2), 175-189. 